\title{
Peer Feedback Practice in EFL Tertiary Writing Classes
}

\author{
Ha Thi Nguyen ${ }^{1}$ \\ ${ }^{1}$ Faculty of English, Hanoi National University of Education, Vietnam \\ Correspondence: Ha Thi Nguyen, Faculty of English, Hanoi National University of Education, Hanoi, Vietnam. \\ Tel: 61-416-545-524. E-mail: tuanha407@yahoo.com
}

Received: March 22, 2016 Accepted: April 30, 2016 Online Published: May 3, 2016

doi: 10.5539/elt.v9n6p76 URL: http://dx.doi.org/10.5539/elt.v9n6p76

\begin{abstract}
Peer feedback plays a pivotal role in stimulating students' participation in L2 writing, which has the potential to develop students' writing skills. The concept of metacognition has also been examined to facilitate learner writers in their learning process. As such, this study drawing upon the concept of metacognition explores the implementation of peer feedback in English as a foreign language (EFL) tertiary writing classes in Vietnam and based on the findings develops a peer feedback approach to enhance the learners' metacognition. Data were collected from semi-structured interviews with sixteen English majors and classroom observations in two English writing classes at a university in Vietnam. Content analysis of the data revealed that peer feedback was informally implemented in two EFL writing classes under study, which might suggest that few opportunities for the students to develop their metacognition could be provided in this current feedback approach. The findings also demonstrated the learners' expectations for changes in peer feedback practice in their writing classes. Thus, the study suggested a jigsaw peer feedback approach which met the participants' desires and simultaneously afforded the learners a number of opportunities to improve their metacognition in EFL writing contexts, especially in Vietnam. This study helps to extend the literature in peer feedback approach in L2 writing which is underpinned by the concept of metacognition and offers both pedagogical and theoretical implications in English language teaching (ELT).
\end{abstract}

Keywords: peer feedback, EFL writing, English language teaching, metacognition, tertiary education

\section{Introduction}

Peer feedback has been widely considered to be one of the effective strategies to facilitate teacher feedback on writing skills (Diab, 2010; Ekşi, 2012; Ferris, 2003; Nelson \& Schunn, 2008; Rollinson, 2005) and to improve learners' writing skills (Berg, 1999; Lundstrom \& Baker, 2009; Min, 2006). Naturally, peer feedback focuses much on learners' engagement in learning process so that it can promote the learner-centred approach. Likewise, metacognition has been examined to support language learners in their learning process (Hartman, 2001; Schraw, 2001), and it also enhances the learner-centred approach. The reciprocal relationship between L2 learners' writing skills and metacognition has been confirmed in prior research (Hacker, Keener, \& Kircher, 2009; Lv, 2010; Wei, Shang, \& Briody, 2012; Xiao, 2007). An awareness of metacognition in language teaching and learning generally and in English writing skills particularly will contribute significantly to students' language acquisition. Nonetheless, to date little research has been conducted to examine the correlation between peer feedback approach in English writing skills and English language learners' metacognition development. Thus, this study, one part of a larger project, primarily aims to examine current peer feedback practice in EFL tertiary writing classes in Vietnam. Based on the findings, the study suggests an appropriate peer feedback approach in EFL writing clases with an attempt to stimulate the learners' metacognitive awareness and skills. In what follows, an insight into the concept of metacognition and a review of peer feedback practice in ESL (English as a second language) and EFL writing classrooms will be presented to highlight the gaps to be addressed in this study.

\section{The Concept of Metacognition}

Metacognition plays a crucial role in second language teaching and learning in general (Anderson, 2002; W. Y. K. Lam, 2009; O’Malley \& Chamot, 1990; Pintrich, 2002; Raoofi, Chan, Mukundan, \& Rashid, 2014; Wenden, 1999) and in L2 writing in particular (Harris, Graham, Brindle, \& Sandmel, 2009; Lv, 2010; Negretti, 2012; Negretti \& Kuteeva, 2011; Wei et al., 2012; Xiao, 2007; Yanyan, 2010). Originally, the notion of metacognition is defined by Flavell (1979) as the human ability to reflect on one's knowledge and control one's knowledge and thinking. Based on Flavell's (1979) concept of metacognition, researchers have attempted to simplify this notion 
as "understanding and control of cognitive processes" (Sternberg, 1998, p. 128) or "thinking about thinking" (Anderson, 2002, p.1). Specifically, the concept of metacognition may be defined by Taylor (1999) as:

an appreciation of what one already knows, together with a correct apprehension of the learning task and what knowledge and skills it requires, combined with the ability to make correct inferences about how to apply one's strategic knowledge to a particular situation, and to do so efficiently and reliably. (p. 37).

According to Schraw (2001), there are two components in the concept of metacognition, "knowledge of cognition and regulation of cognition" (p. 3). Firstly, knowledge of cognition encompasses declarative, procedural, and conditional knowledge. Declarative knowledge refers to "knowledge about oneself as a learner and what factors influence one's performance" (Schraw, 2001, p. 4). Procedural knowledge is knowledge about doing things. As explained by Schraw (2001), it refers to knowledge about how to do things and "is represented as heuristics and strategies" (p. 4). Conditional knowledge refers to knowledge about "the "why" and "when" aspects of cognition" (Schraw, 2001, p. 4). Secondly, regulation of cognition consists of three essential skills which enable students to control their learning (Schraw, 2001). These skills include: planning, monitoring, and evaluating. Planning is the skill of selecting proper strategies and resources "that affect performance" (Schraw, 2001, p. 5). Monitoring means one's knowledge about understanding and performing a task. Evaluating means "appraising the products and efficiency of one's learning" (Schraw, 2001, p. 5). In general, these metacognitive skills are actual strategies being utilized to control and regulate cognitive activities.

In order to give an overall view about the concept of metacognition, I summarize its two components in the following figure based on Schraw's (2001) description.

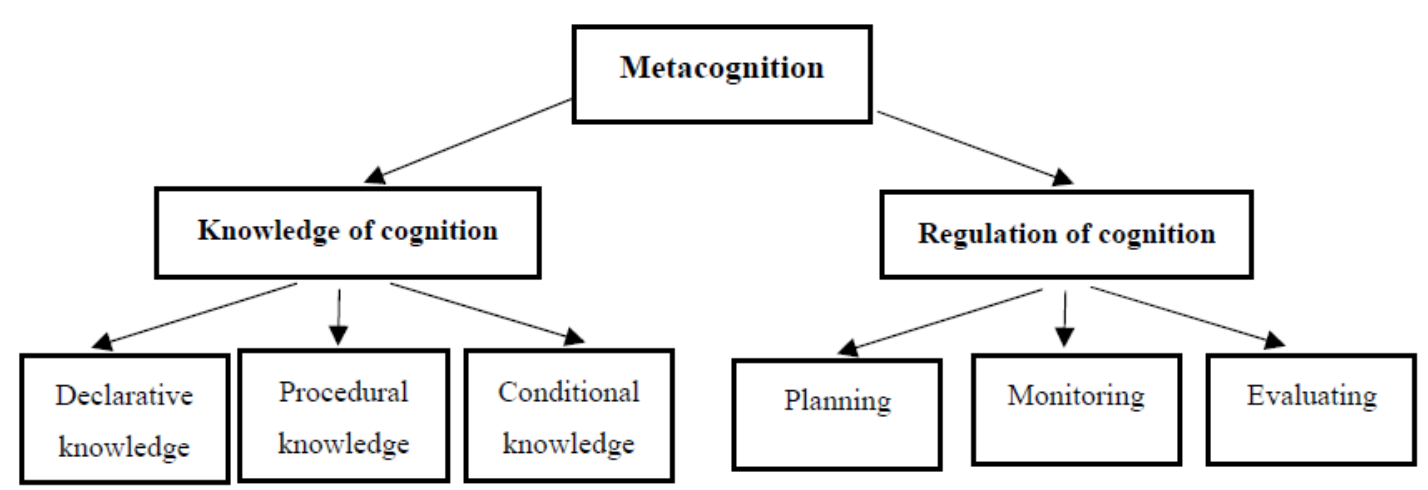

Figure 1. Components of metacognition (Schraw, 2001)

\section{Peer Feedback in L2 Writing}

Peer feedback, also known as peer response or peer review, is defined as a collaborative activity in which students read, critique and give feedback on one another's writing to facilitate writing competence through mutual scaffolding (Hu, 2005; Tsui \& Ng, 2000; Zhu, 2001). Given its potential advantages in developing students' learning, peer feedback practice has attracted ample research attention from various scholars in L2 writing (see also Ferris, 2003; Hu, 2005; R. Lam; 2010; Min, 2016).

A substantial amount of research has shown explicit instructions about peer feedback training and its positive impacts on English language learners. For instance, specific instructions are mainly given for three stages of before, during, and after peer responses to maximize the effects of peer response (Hansen \& Liu, 2005; Hu, 2005; R. Lam, 2010; Rollinson, 2005; Zhao, 2014). Explicit instructions about involving language learners in peer response focus on the real practice with authentic exemplars (R. Lam, 2010) together with teachers' assistance during the practice (Hansen \& Liu, 2005; R. Lam, 2010; Min, 2005, 2006; Zhao, 2014). Instructions about post peer response emphasize promoting students' self-reflection or learner autonomy after engaging in the activity (Hansen \& Liu, 2005; R. Lam, 2010). As a result, peer feedback training helps to confirm of language learners' abilities and skills in providing feedback ( $\mathrm{Hu}, 2005$; Min, 2005, 2006, 2016). It can also contribute to improve EFL students' language acquisition and writing skills (Min, 2005, 2006) or develop English language learners' confidence and motivation in the activity participation (Hansen \& Liu, 2005; Hu, 2005; Min, 2005, 2006).

In the Vietnamese context, an emphasis on peer feedback training and effects of its implementation on English 
language learners has also been documented. For instance, Pham and Gillies (2010) suggest that issues about Vietnamese students' learning culture should be taken into consideration when implementing peer assessment. Particularly, Vietnamese students are not willing to be involved in intragroup peer assessment because of their lack of confidence in providing feedback directly and in a face-to-face mode. Rather, they are in favour of participating in intergroup peer assessment in which they can avoid conflicts in the interests of face. In another study investigating Vietnamese EFL students' perceptions of peer feedback given to their writing blogs, T. T. P. Nguyen (2012) argues that writing blogs has a positive impact on developing the students' motivation and independent learning and emphasises that training students to give effective comments on peers' blog is necessary. Additionally, training oral peer feedback by using teachers' form-focused instruction implicitly and explicitly has the potential to improve Vietnamese high-intermediate EFL students' pragmatic competence (T. T. M. Nguyen, 2013; T. T. M. Nguyen, Pham, \& Pham, 2012). Recently, M. H. Nguyen (2013) suggested that oral peer feedback was one of the six categories of peer scaffolding behaviours which was conducive to improve EFL learners' performance in oral presentations at a Vietnamese university.

Prior research also indicates that there are controversial arguments about true efficacy of peer feedback on English language learners. On the one hand, peer feedback helps to promote language learner autonomy in process approach to writing (Ekşi, 2012; Yang, Badger, \& Yu, 2006), create a friendly and secure environment for language learners (Sato, 2013; Yang et al., 2006), and develop learners' writing skills in subsequent writing drafts (Diab, 2010; Lundstrom \& Baker, 2009). On the other hand, popular concerns about true efficacy of peer feedback relate to students' limited knowledge of the language, trustworthiness of feedback provided by peers on a wide range of errors and students' inappropriate attitude towards peer response (see $\mathrm{Hu}, 2005$ ). Another concern is that peer feedback is not as effective as teacher feedback in developing EFL students' writing (Ruegg, 2014, 2015).

Overall, the above reviewed literature illustrated that the majority of prior research examined peer feedback training and practice in ESL/EFL writing contexts by employing experimental research designs (Diab, 2010; Ekşi, 2012; Lundstrom \& Baker, 2009; Min, 2016; T. T. M. Nguyen, 2013; T. T. M. Nguyen et al., 2012; Ruegg, 2014, 2015) or a mixed methods approach (Min, 2005, 2006; Yang et al., 2006; Zhao, 2014). A relatively smaller number of prior studies adopted a qualitative approach to investigate the phenomenon. Indeed, research examining feedback strategies conducted in controlled settings seems to be irrelevant to language teachers since it fails to reflect authentic classroom conditions (Storch, 2010). Thus, more qualitative studies should be carried out to investigate peer feedback practice in L2 writing (Lundstrom \& Baker, 2009). Also, prior research failed to draw upon the concept of metacognition to explore the practice of peer feedback in L2 writing classes. Furthermore, previous empirical research merely valued the positive impacts of paired peer feedback training instead of group peer response coaching. Therefore, their suggestions and claims about effects of peer feedback training cannot be generalizable in different settings and conditions. My qualitative research is an attempt to address the above gaps by investigating the current peer feedback practice in two EFL tertiary writing classes in Vietnam and developing an approach of group peer response in English writing classes based on the concept of metacognition. To achieve the aims, the following research questions form the basis of the study:

1) How is peer feedback currently utilized and perceived by students in EFL tertiary writing classes in Vietnam?

2) How can the information be used to develop an appropriate peer feedback approach to stimulate the EFL learners' metacognition and their engagement in this feedback practice?

\section{Method}

This study employed a qualitative research approach (Creswell, 2013; Lichtman, 2014; Patton, 2002) to respond to the above research questions. In this section, information about the setting such as the participants and the writing course will be briefly described before presentations about methods of data collection and analysis are illustrated.

\subsection{The Participants and the Writing Course}

English major students in two classes of the third year English writing course of the Bachelor in teaching EFL program in the Faculty of English Language Teacher Training, University of Success in Vietnam (pseudonyms) were invited to take part in the research. Their language proficiency levels were of between intermediate and upper intermediate levels, equivalent between B1 and B2 levels in the Common European Framework of Reference for Languages (CEFR). There were 49 students in these two writing classes. All of the students participated in video-recorded classroom observations. Eight students in each class were selected to attend the individual semi-structured interviews to provide detailed information about peer feedback practice in their writing classes, which facilitated the researcher to obtain an in-depth understanding about the phenomenon under 
study.

In the first 15-week writing semester of the third year program, the students were taught how to write academic essays which described the information presented in a line graph, a chart, a table, or a process. This writing task is adapted from writing task 1 in IELTS academic writing test. The course book for internal use in this faculty was compiled from various sources of Writing IELTS books. The objectives of the course and a list of references for practising this writing task were introduced to the students at the beginning of the semester.

\subsection{Data Collection and Analysis}

In this qualitative research, data collection was conducted from individually audio-recorded semi-structured interviews (30-45 minute each) and video-recorded classroom observations (two 50-minute writing sessions in each class). Data were gathered in the ninth and tenth weeks of the 15-week semester. All of the information collected from each individual interview was transcribed and sent back to the participants for their verification and approval before being analysed in combination with the observation data.

Content analysis was utilized as the main method of data analysis and interpretation in this study. It was conducted according to recommendations by Lichtman (2014) and Patton (2002). Specifically, I adopted the strategy of the Three Cs (i.e. coding, categorizing, and concepts) recommended by Lichtman (2014) to seek major themes from interview data and observation data. In other words, data analysis in this study was done in an inductive process in which the researcher discovered major themes and categories from detailed and specific data (Creswell, 2013; Lichtman, 2014). Similar findings were labeled and then grouped together into sub-themes to highlight the content in interview data which was then supported by observation data. In addition to the data-driven approach, data analysis in this study was conducted with theory-driven and prior-research driven approaches suggested by Boyatzis (1998). Specifically, data were interpreted in accordance with the concept of metacognition and the literature on peer feedback in L2 writing classes.

\section{Results and Discussions}

In this section, responses to the two research questions are presented and discussed in the key themes arising from data analysis as follows.

\subsection{Research Question 1}

Interview and observation data revealed three major themes of the current peer feedback approach in two EFL writing classes, namely current peer feedback practice, participants' perspectives about its effects, and their desire for changes in this feedback type, as will now be discussed.

\subsubsection{Peer Feedback Practice}

The interview data indicated that peer feedback was informally implemented to involve the learners in the activity. Indeed, peer feedback was advised to use by the lecturer in Class A at the beginning of the semester, but it was not in serious practice. In a similar vein, it was not formally implemented in Class B on a regular basis. Six students in Class A shared the same opinions with Quynh and seven students in Class B agreed with Mai about the utilization of peer feedback in their writing classes. For instance, they said:

In this writing semester, the lecturer asked us to do peer feedback by ourselves outside class hours with a suggested checklist, but she did not double check whether we did it or not. (Quynh)

Peer feedback was not formally used in this writing semester in my class. The lecturer only advised us to do peer feedback by ourselves. (Mai).

The classroom observation data revealed that peer feedback practice was utilized in one extra class activity in each writing class. The extra activities were similar in their nature in two classes and took place in the beginning of one observed writing session in each class. Particularly, the lecturers selected one writing sample on which they asked students to give feedback. Their management of this extra peer feedback was documented in three steps. Firstly, the lecturers selected students for each pair and group. Secondly, before each peer feedback activity, the lecturers suggested some questions and wrote them on the board as clear guidance for the peer feedback focus. Thirdly, during the activity, the lecturers became both observers and facilitators by monitoring and assisting students if needed.

An issue about the organisation of peer feedback in these extra class activities emerged when the lecturers set up pairs or groups in the observed extraneous classes. The lecturers simply grouped the students according to who they were sitting next to. This observation might suggest that the lecturers had few criteria for organizing pairings or groupings. Such an unfocused decision goes against what has been found in research on effective feedback, and that is, the need for careful planning and decision-making in setting up groups. To be noted is that 
there is a variety of views about groupings in the literature. For example, Hansen and Liu (2005) suggested letting students select their own groups. Similarly, Lee (1997) recommended that: "it is important that students work in a pair or a group where they feel comfortable. They also need to develop trust in each other." (p. 63). Rollinson (2005) emphasized that thought needed to be given to group size for maximising peer feedback. The important conclusion from this research, however, which will have implications for the present study, is that groupings need to be planned.

To provide a further insight into the implementation of peer feedback in this study, the following section will present participants' perceptions of the effectiveness of this feedback approach.

\subsubsection{Participants' Perspectives about Effects of Peer Feedback}

The investigation disclosed that there were contrasting opinions about peer feedback effectiveness among the participating students. Firstly, in terms of the students' support for peer feedback, six students who were conscious about the importance of peer feedback stated that they normally asked their friends to read and give comments on their work. They asserted that they could improve their language from their peer responses. They also reported that they felt more comfortable when asking for help from friends than from teachers. The following statements represent the students' positive thoughts about the efficacy of peer feedback:

I often do peer feedback with my friends. I find that their comments are very useful especially on grammar and vocabulary errors.... I think if we do peer feedback seriously, effectiveness will appear. (Bich)

In this writing semester, peer feedback was indeed a voluntary activity. Sometimes, I asked my best friend to check my writing. I found it effective because my friend had different thoughts and experience from which I could learn more about how to improve my writing skills. (Nga).

The above results revealed that these students were aware of promoting their learning from this feedback practice. This means they were quite active in their learning or that their learner autonomy could be developed when they engaged in peer feedback. This finding concurs with prior research which showed that peer feedback exerted a positive impact on developing student autonomy (Ekşi, 2012; Lundstrom \& Baker, 2009; Yang et al., 2006).

However, the majority of the students doubted the efficacy of peer feedback. The following excerpts clearly illustrate:

Peer feedback was not effective at all because we didn't do it seriously. It was not compulsory, you know... And, students usually think that it is not very useful if their drafts are checked by their peers... In general we didn't spend much time doing peer feedback because of the two reasons: (1) we were lazy and (2) we believed that peer check was not really effective. Personally, I think that peer feedback hasn't been seriously implemented in my group. I believe that if it is well-organized, it will work effectively... (Lan).

Peer feedback is the cooperation between two students and it is difficult to evaluate their correction because they do it on their own ways and feelings. Although the lecturer gave us a checklist for feedback, we tended to focus on grammar and spelling errors. We couldn't look at unity, coherence, ideas. Also, students in my class have different levels of English language proficiency so students with a lower level do not normally feel confident in giving feedback to drafts written by those with a higher language proficiency. (Ngoc).

From the students' voices, two major reasons emerged to justify their views. The first one was that this kind of feedback was neither well-implemented nor strictly-controlled in these writing classes. Another reason was that the students expressed their distrust in their peers' language proficiency, which supports scholars' claim about learners' belief that peers are not qualified to critique their writing (Leki, 1990; Rollinson, 2005; Tsui \& Ng, 2000; Yang et al., 2006).

A more insightful picture of the participants' thoughts about peer feedback practice was demonstrated through their desire for changes, which will be discussed in the following section.

\subsubsection{Participants' Desire for Innovation}

All participating students expressed a desire for stimulating their engagement in peer feedback. First of all, they insisted on having an appropriate and understandable checklist for self- or peer-editing. The students highly appreciated their lecturers' intense involvement in preparing and organizing peer feedback practice with explicit guidance or orientation. For instance, Minh said:

The lecturer introduced a checklist for the students to self-edit and peer check in this semester. However, I found it impractical. If the lecturer can provide a more detailed particular and comprehensible checklist, students will participate more actively in peer feedback. 
The above finding suggested that the checklist could be utilized to enhance the students' participation in peer feedback practice. This means the checklist could be regarded as a tool to stimulate student' learning and/or encourage students in effective collaborative work, which supports the suggestion that clear guidelines were of paramount importance in effective peer review (Rollinson, 2005).

Secondly, ten out of sixteen students in the study supported the idea of implementing peer feedback in an appropriate approach. They believed in the positive impacts of student-student interaction and collaboration on student writing improvement. For instance, Bich thought peer feedback could create a friendly atmosphere. She said: "In peer feedback, we feel free to ask our friends any questions and give our constructive comments on peers' essays. Peer feedback will work effectively if we do it seriously." Lien and Mai also appreciated quality of peer feedback since they believed they could develop their language from their friends' feedback. They commented:

Learning from teachers is not as good as learning from friends. We can learn a lot from our friends, especially advanced and very good students so I wish to have formal and regular peer feedback practice in my writing class. (Lien).

I think that we find it more difficult to recognize our own errors than my friends doing it for us. When other writers check our drafts, they will be able to locate errors quickly and suggest for error correction appropriately. In this sense, peer feedback will work effectively (Mai).

Minh shared a similar opinion with eight students when suggesting that peer feedback should be implemented in small groups of three or four students to maximize its positive impacts on student writing progress. She said:

For peer feedback, I want to work in small groups of three or four students so that we can exchange our writing drafts, learn to avoid errors made in other friends' writing, and learn good expressions from different friends.

The above findings indicated that the learners did believe that benefits could accrue from peer reviews as they felt comfortable working with their friends. In other words, the students in this study recognized the potential value of peer feedback in strengthening their writing skills. The result concurs with prior research which also highlighted learners' beliefs and preferences for peer feedback due to its benefits in developing their writing (Ekşi, 2012; Sato, 2013; Yang et al., 2006; Zhao, 2014). Particularly, it strongly supports Sato's (2013) findings that "L2 learners see their classmates as learning resources" and "both peer interaction and peer CF [corrective feedback] were effective for language development" (p. 626).

In summary, the investigation about current peer feedback practice revealed that this feedback type was not formally implemented in two EFL tertiary writing classes under study. The majority of the students were unwilling to utilize peer feedback outside class. Yet, they could recognize the benefits of the feedback approach in their writing development. The results may suggest that despite being aware of the potential value of peer feedback, the students could not teach themselves nor prioritize it as a strategy in their own time unless it became a part of the syllabus and formal assessment processes. This finding can confirm the Vietnamese's common belief that learning normally occurs in class and under severe supervision of educational institutions (Duong, 2006). It can be inferred from the results that few opportunities might be provided for the students to develop their metacognitive awareness and skills from this informal peer feedback approach. Therefore, the following section suggests a peer feedback approach in English writing classes which may be adapted not only for the EFL tertiary learners in this study but also for English language learners in other EFL/ESL contexts to enhance learners' engagement and metacognitive knowledge and strategies in peer feedback.

\subsection{Research Question 2}

Based on the above findings, guidelines and principles suggested in previous studies about peer feedback (Hansen \& Liu, 2005; R. Lam, 2010; Rollinson, 2005), and the concept of metacognition, the researcher has developed a group feedback approach, called jigsaw peer feedback. Indeed, after being developed the approach was piloted in the two EFL writing classes under study. However, in this paper, I only present about how the approach was built up by (1) illustrating the development of the Yes/No checklist and (2) giving instructions about the implementation of the jigsaw peer feedback.

\subsubsection{Yes/No Checklist Development}

With an aim to balance feedback delivery on students' writing, a checklist focusing on a set of main criteria and spaces of comments needed to be developed. For instance, criteria such as ideas, organization, vocabulary, and grammar were included in the checklist to ensure that both language and content were checked (Ferris, 2003; Lee, 2011). Furthermore, Nelson and Schunn (2008) believed that: "feedback should include a summary of performance, $[\ldots]$, and suggestions in how to improve performance $[\ldots]$ Feedback should also be fairly specific 
when referring to global issues" (p. 395). Thus, to encourage feedback reviewers to provide comments and/or suggestions for improvement, corresponding spaces with specific criteria and at the end of the checklist for overall comments were given in the checklist (see Appendix B).

Additionally, in order to stimulate the students' understanding of the criteria in the checklist as well as help them know how to improve their writing, all of the sub-items in each category were stated as clearly as possible. Ferris (2003) and Hyland (2003) suggested how to develop a checklist by giving clear and specific questions on different feedback criteria. The effectiveness of a Yes-No question checklist has also been examined on peer response guidance by Ekşi (2012). As such, the researcher selected the design of Yes-No questions for the checklist users in this study since they could facilitate students to figure out relevant information to each specific question.

With respect to stimulating the students' metacognition, the checklist was developed for the learners to use in the roles of both a feedback giver and a feedback receiver. In the first role, students' metacognitive monitoring could be promoted when they had to think of the appropriate answer for each of Yes or No questions in the checklist. Serra and Metcalfe (2009) argued that "metacognitive monitoring focuses on the progress of the cognitive process in which the person is engaged." They suggested that a YES/NO pattern could lead to explicit judgments in which monitoring skill was presented. Furthermore, there was a ranking scale of A, B, C, D, and E (equivalent to excellent, very good, good, fair, and poor levels respectively) in the corresponding Yes columns. Letter grades, a popular type of grading methods, are "convenient and simple to use", but "it is often hard to determine and justify the cut-off points between grade categories" (Berry, 2008, p.126). Thus, the process of determining the proper rank was assumed to be one of the challenging tasks for feedback givers. At this stage, students were required to activate their thinking about thinking in order to determine what would be an appropriate assessment of their peers' writing (see Ferris, 2003; Hyland, 2003). This was another opportunity for the students to promote their metacognitive knowledge. Moreover, as feedback givers, students were required to add some written notes to clarify their feedback which could promote their metacognitive awareness about error analysis. These notes could be added in the columns of examples of errors and suggestions for improvement in the checklist. This is also one of the recommendations suggested by Ferris (2003) and Hyland (2003) in the design of a checklist, which highlights the importance of open-ended responses when giving feedback. Hence, it was necessary to leave spaces for feedback providers to write end comments in the checklist.

In the role of a feedback receiver, this checklist created an opportunity for students to regulate their awareness of errors in their writing through a self-editing process or through revising their drafts according to feedback received from their peers ( Nguyen, 2009). With this checklist, the students were able "to bear in mind the aims of their work and to assess their own progress to meet these aims as they proceed" and they would "become independent learners" (Black et al., 2007, p. 107). In this respect, the students' skills of monitoring and assessing their writing could be reinforced, leading to the potential for regulation of cognition to be developed. This argument is strongly supported by Hacker et al. (2009) who claimed there was a close connection between writing and metacognition. They pointed out that:

Reading, re-reading, reflecting, and reviewing are used as monitoring strategies of our own thoughts. Editing, drafting, idea generation, word production, translation, diagnosing, and revision are used as control strategies of our own thoughts. The monitoring and control of our own thinking is metacognition. (p. 161).

To sum up, it was assumed that with the checklist students would know how to plan, monitor, and evaluate their own writing, allowing their regulation of cognition to be stimulated. In order to provide further insights into the jigsaw peer feedback, the following section illustrates specific instructions about how to implement this approach in English writing classes.

\subsubsection{Guidelines for Jigsaw Peer Feedback Implementation}

Jigsaw peer feedback was, indeed, group feedback practice since there were four students working in one group to be in charge of providing feedback on their peers' writing instead of the usual practice of paired peer feedback. This format of the peer response was primarily developed from student participants' voices for group feedback and from Ferris' (2003) belief in the efficacy of group feedback that "a more diverse audience" will bring about "multiple perspectives" (p. 70). Every student in each group would provide feedback on one criterion (ideas, organization, vocabulary, or grammar) to four first drafts written by their peers who were in a different group. Then, complete feedback on all of the above criteria was returned to the writers. This was regarded as "the application of intergroup peer assessment, instead of intragroup peer assessment" (Pham \& Gillies, 2010, p. 81). In this sense, it was hoped that the students could avoid being afraid of giving straightforward, constructive or even negative feedback on their peers' writing in the same group. This argument is strongly supported by Pham and Gillies' (2010) suggestion that 
Vietnamese students will participate actively and effectively in peer activities if they feel safe to show their opinions and save face in front of their friends. An overall insight into the jigsaw peer feedback is illustrated in Figure 2, followed by instructions about (1) grouping students in the peer activity and (2) a training session to familiarize students with this feedback approach.

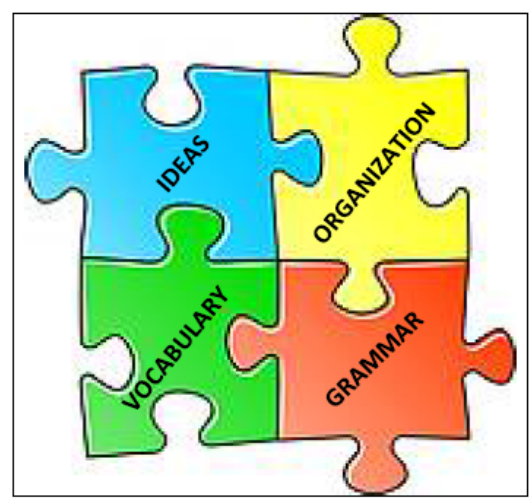

Figure 2. Jigsaw peer feedback

Firstly, grouping students in peer response was set up with a focus on creating a comfortable and trustworthy environment for the activity (Berg, 1999; Hyland, 2003; Lee, 1997; Rollinson, 2005). In order to establish a comfortable atmosphere for group feedback, students were first allowed to make their own choice of one category (ideas, organization, vocabulary, or grammar) on which to provide feedback. It was considered important to provide students with a preference to increase their motivation to participate in the task (Ellis, 2008). In the event that there were too many students selecting the same categories to give feedback, lecturers made the final selection to balance the number of feedback providers for each criterion. The lecturers based their ultimate decision on the students' exam outcomes from the previous semester and their belief in the learners' language competence. So as to stimulate the assistance among members in one group, each group had at least one member whose English proficiency was slightly higher than the others (Ferris, 2003; Hyland, 2003). Ferris (2003) believes in the potential benefit for a mixed group of strong and weak student writers. She claimed: "[t]he weaker writers benefit from regularly reading the texts of more proficient writers, and the more advanced writers profit from the critical thinking required to give helpful feedback to their less able classmates." (p. 170).

Secondly, a two hour training session was essential to strengthen students' understanding about their task commitment. The training session began with the lecturer's clarification about the checklist. In so doing, the lecturer successfully accomplished the responsibility in instructing learners to perform their task properly. Simultaneously, the students were able to take an advantage of an opportunity to develop their metacognitive knowledge. This argument is vigorously supported by Berry's (2008) claim that "metacognitive skills must be developed, and many learners will not develop these skills without explicit guidance from teachers" (p.11). After the lecturer's explanations about the checklist, there was a model presentation of how the group feedback activity worked as Brookhart (2008, p. 58) stressed: "modelling is one of the best ways to teach". The training activity was based on the claim that coaching of peer feedback in English writing classes can be effective (Berg, 1999; Bitchener \& Ferris, 2012; Ferris, 2003; Lam, 2010; Min, 2005, 2006, 2016; Rollinson, 2005).

In order to facilitate students' understanding about their assigned task in group feedback, the students in charge of providing feedback on the same criterion worked together in one group in this training session. This means that there were four groups, and each group provided feedback on one of the four criteria: ideas, organization, vocabulary, or grammar. Prior to this, the lecturer had selected one sample answer in the IELTS academic writing task to which the groups were expected to apply their chosen feedback. During this model presentation, the lecturer monitored and helped students to accomplish their task using the checklist. The lecturer concluded the training session by summarising what each member in each group had to do when giving feedback to their peers' first drafts and how this was to be done.

\section{Conclusion}

This qualitative study examined the current peer feedback practice in two EFL tertiary writing classes in Vietnam, and based on the students' perceptions of this feedback approach it developed a jigsaw peer feedback 
approach to stimulate the learners' metacognitive awareness and skills. The findings revealed that peer feedback practice was not formally implemented in this specific context, and this means that few opportunities for the EFL learners to enhance their metacognition could be provided from this feedback approach. As well, participants expressed their expectations for innovating peer feedback practice in their English writing classes. Thus, the jigsaw peer feedback approach was developed with an attempt to afford the learners a number of opportunities to promote their metacognition in language learning and their engagement in peer feedback practice.

The findings in this study offer both pedagocial and theoretical implications in ELT. Pedagogically, the suggested jigsaw feedback approach can be adapted in other EFL or ESL writing contexts to strenghthen the learner-centred approach. Theoretically, the study is among the first attempts to explore the concept of metacognition in peer feedback in L2 writing. Thus, it helps to extend the body of literature in peer feedback practice in English writing classes, especially in EFL higher education.

However, the study is obviously limited by its small size and tools of data collection. Therefore, the findings still await further confirmation for the generalizability. It would be insightful for further research to collect additional document data, i.e., student writing products to examine the true efficacy of current peer feedback on learners' writing improvement. Futher studies might also investigate a combination of this jigsaw peer feedback and another feedback type in L2 writing to maximize language learners' metacognition.

\section{References}

Anderson, N. J. (2002). The role of metacognition in second language teaching and learning. Eric Clearninghouse on Languages and Linguistics, 01(10).

Berg, E. C. (1999). The effects of trained peer response on ESL students' revision types and writing quality. Journal of Second Language Writing, 8(3), 215-241. http://dx.doi.org/10.1016/S1060-3743(99)80115-5

Berry, R. (2008). Assessment for Learning. Hong Kong: Hong Kong University Press. http://dx.doi.org/10.5790/hongkong/9789622099579.001.0001

Bitchener, J., \& Ferris, D. R. (2012). Written Corrective Feedback in Second Language Acquisition and Writing. New York and London: Routledge.

Boyatzis, R. E. (1998). Transforming qualitative information: Thematic analysis and code development. Thousand Oaks, CA: Sage Publications.

Brookhart, S. M. (2008). How to give effective feedback to your students. Alexandria, VA: Association for Supervision and Curriculum Development.

Creswell, J. W. (2013). Qualitative Inquiry and Research Design: Choosing among the five approaches (3rd ed.). Thousand Oaks: SAGE Publications.

Diab, N. M. (2010). Effects of peer- versus self-editing on students' revision of language errors in revised drafts. System, 38, 85-95. http://dx.doi.org/10.1016/j.system.2009.12.008

Duong, T. H. O. (2006). Learner Autonomy in a Asian Context: Independent Learning and Independent Work at the University Level (Vietnam). In T. S. C. Farrell (Ed.), Language Teacher Research in Asia (pp. 35-46). Virginia, The USA: Teachers of English to Speackers of Other Languages, Inc.

Ekşi, G. Y. (2012). Peer review versus teacher feedback in process writing: how effective? International Journal of Applied Educational Studies, 13(1), 33-48.

Ellis, R. (2008). The study of Second Language Acquisition. Oxford: Oxford University Press.

Ferris, D. R. (2003). Response to Student Writing. Mahwah, N.J.: Lawrence Erlbaum Associates, Inc.

Flavell, J. H. (1979). Metacognition and cognitive monitoring. American Psychologist, 34(10), 906-911. http://dx.doi.org/10.1037/0003-066X.34.10.906

Hacker, D. J., Keener, M. C., \& Kircher, J. C. (2009). Writing is applied metacognition. In D. J. Hacker, J. Dunlosky, \& A. C. Graesser (Eds.), Handbook of Metacognition in Education (pp. 154-172). New York and London: Routledge.

Hansen, J. G., \& Liu, J. (2005). Guiding principles for effective peer response. ELT Journal, 59(1), 31-38. http://dx.doi.org/10.1093/elt/cci004

Harris, K. R., Graham, S., Brindle, M., \& Sandmel, K. (2009). Metacognition and children's writing. In D. J. Hacker, J. Dunlosky, \& A. C. Graesser (Eds.), Handbook of Metacognition in Education (pp. 131-153). New York and London: Routledge. 
Hartman, H. J. (2001). Developing students' metacognitive knowledge and skills. In H. J. Hartman (Ed.), Metacognition in Learning and Instruction (pp. 33-68). Dordrecht; London: Kluwer Academic Publishers. http://dx.doi.org/10.1007/978-94-017-2243-8_3

Hu, G. (2005). Using peer review with Chinese ESL student writers. Language Teaching Research, 9(3), 321-342. http://dx.doi.org/10.1191/13621688051r169oa

Hyland, K. (2003). Second Language Writing. Cambridge, UK ; New York, N.Y: Cambridge University Press. http://dx.doi.org/10.1017/CBO9780511667251

Lam, R. (2010). A peer review training workshop: coaching students to give and evaluate peer feedback. TESl Canada Journal, 27(2), 114-127.

Lam, W. Y. K. (2009). Examining the effects of metacognitive strategy instruction on ESL group discussions: A synthesis of approaches. Language Teaching Research, 13(2), 129-150. http://dx.doi.org/10.1177/1362168809103445

Lee, I. (1997). Peer reviews in a Hong Kong tertiary classroom. TESI Canada Journal, 15(1), 58-69.

Lee, I. (2011). Working smarter, not working harder: Revisiting teacher feedback in the L2 writing classroom. The Canadian Modern Language Review, 67(3), 377-399. http://dx.doi.org/10.3138/cmlr.67.3.377

Leki, I. (1990). Coaching from the margins: issues in written response. In B. Kroll (Ed.), Second Language Writing: Research insights for the classroom (pp. 57-68). Cambridge: Cambridge University Press. http://dx.doi.org/10.1017/CBO9781139524551.008

Lichtman, M. (2014). Qualitative Research for the Socical Sciences. Thousand Oaks: SAGE Publications.

Lundstrom, K., \& Baker, W. (2009). To give is better than to receive: The benefits of peer review to the reviewer's own writing. Journal of Second Language Writing, 18, 30-43. http://dx.doi.org/10.1016/j.jslw.2008.06.002

Lv, F. (2010). A study of metacognitive-strategies-based writing instruction for vocational college students. English Language Teaching, 3(3), 136-144. http://dx.doi.org/10.5539/elt.v3n3p136

Min, H.-T. (2005). Training students to become successful peer reviews. System, 33, 293-308. http://dx.doi.org/10.1016/j.system.2004.11.003

Min, H.-T. (2006). The effects of trained peer review on EFL students' revisiion types and writing quality. Journal of Second Language Writing, 15, 118-141. http://dx.doi.org/10.1016/j.jslw.2006.01.003

Min, H.-T. (2016). Effect of teacher modeling and feedback on EFL students' peer review skills in peer review training. Journal of Second Language Writing, 31, 43-57. http://dx.doi.org/10.1016/j.jslw.2016.01.004

Negretti, R. (2012). Metacognition in student academic writing: A longitudinal study of metacognitive awareness and its relation to task perception, self-regulation, and evaluation of performance. Written Communication, 29(2), 142-179. http://dx.doi.org/10.1177/0741088312438529

Negretti, R., \& Kuteeva, M. (2011). Fostering metacognitive genre awareness in L2 academic reading and writing: A case study of pre-service English teachers. Jounal of Second Language Writing, 20(95-110). http://dx.doi.org/10.1016/j.jslw.2011.02.002

Nelson, M. M., \& Schunn, C. D. (2008). The nature of feedback: How different types of peer feedback affect writing performance. Instructional Science: An International Journal of the Learning Sciences, 37(4), 375-401. http://dx.doi.org/10.1007/s11251-008-9053-x

Nguyen, H. H. T. (2009). Teaching EFL writing in Vietnam: Problems and solutions - a discussion from the outlook of applied linguistics. VNU Journal of Science, Foreign Languages, 25, 61-66.

Nguyen, M. H. (2013). EFL students' reflections on peer scaffolding in making a collaborative oral presentation. English Language Teaching, 6(4), 64-73. http://dx.doi.org/10.5539/elt.v6n4p64

Nguyen, T. T. M. (2013). Instructional effects on the acquisition of modifiers in constructive criticism by EFL learners. Language Awareness, 22(1), 76-94. http://dx.doi.org/10.1080/09658416.2012.658810

Nguyen, T. T. M., Pham, T. H., \& Pham, M. T. (2012). The relative effects of explicit and implicit form-focused instruction on the development of L2 pragmatic competence. Journal of Pragmatics, 44(4), 416-434. http://dx.doi.org/10.1016/j.pragma.2012.01.003 
Nguyen, T. T. P. (2012). Peer feedback on second language writing through blogs: The case of a Vietnamese EFL classroom. International Journal of Computer-Assisted Language Learning and Teaching, 2(1), 13-23. http://dx.doi.org/10.4018/ijcallt.2012010102

O’Malley, J. M., \& Chamot, A. U. (1990). Learning Strategies in Second Language Acquisition. Cambridge, England; New York; Melbourne: Cambridge University Press. http://dx.doi.org/10.1017/CBO9781139524490

Patton, M. Q. (2002). Qualitative Research \& Evaluation Methods (3rd ed.). California: Sage Publications.

Pham, T. H. T., \& Gillies, R. (2010). Designing a culturally appropriate format of formative peer assessment for Asian students: The case of Vietnamese students. International Journal of Educational Reform, 19(2), 72-85.

Pintrich, P. R. (2002). The role of metacognitive knowledge in learning, teaching, and assessing. Theory into Practice, 41(4), 219-225. http://dx.doi.org/10.1207/s15430421tip4104_3

Raoofi, S., Chan, S. H., Mukundan, J., \& Rashid, S. M. (2014). Metacognition and second /foreign language learning. English Language Teaching, 7(1), 36-49. http://dx.doi.org/10.5539/elt.v7n1p36

Rollinson, P. (2005). Using peer feedback in the ESL writing class. ELT Journal, 59(1), 23-30. http://dx.doi.org/10.1093/elt/cci003

Ruegg, R. (2014). The effect of peer and teacher feedback on changes in EFL students' writing self-efficacy. The Language Learning Journal, 1-18. http://dx.doi.org/10.1080/09571736.2014.958190

Ruegg, R. (2015). The relative effects of peer and teacher feedback on improvement in EFL students' writing ability. Linguistics and Education, 29, 73-82. http://dx.doi.org/10.1016/j.linged.2014.12.001

Sato, M. (2013). Beliefs about peer interaction and peer corrective feedback: Efficacy of classroom intervention. Modern Language Journal, 97(3), 611-633. http://dx.doi.org/10.1111/j.1540-4781.2013.12035.x

Schraw, G. (2001). Promoting general metacognitive awareness. In H. J. Hartman (Ed.), Metacognition in Learning and Instruction (pp. 3-16). Dordrecht, London: Kluwer Academic Publishers. http://dx.doi.org/10.1007/978-94-017-2243-8_1

Serra, M. J., \& Metcalfe, J. (2009). Effective implementation of metacognition. In D. J. Hacker, J. Dunlosky, \& A. C. Graesser (Eds.), Handbook of Metacognition in Education (pp. 278-298). New York and London: Routledge.

Sternberg, R. J. (1998). Metacognition, abilities, and developing expertise: What makes an expert student? Instructional Science, 26(1), 127-140. http://dx.doi.org/10.1023/A:1003096215103

Storch, N. (2010). Critical feedback on written corrective feedback research. International Journal of English Studies, 10(2), 29-46.

Taylor, S. (1999). Better learning through better thinking: Developing students' metacognitive abilities. Journal of College Reading and Learning, 30(1), 34-45. http://dx.doi.org/10.1080/10790195.1999.10850084

Tsui, A. B. M., \& Ng, M. (2000). Do secondary L2 writers benefit from peer comments? Journal of Second Language Writing, 9(2), 147-170. http://dx.doi.org/10.1016/S1060-3743(00)00022-9

Wei, Z.-F., Shang, H.-F., \& Briody, P. (2012). The relationship between English writing ability levels and EFL learners' metacognitive behaviour in the writing process. International Journal of Academic Research in Progress Education and Development, 1(4), 154-180.

Wenden, A. L. (1999). An introduction to metacognitive knowledge and beliefs in language learning: Beyone the basics. System, 27, 435-441. http://dx.doi.org/10.1016/S0346-251X(99)00043-3

Xiao, Y. (2007). Applying metacognition in EFL writing instruction in China. Reflections on English Language Teaching, 6(1), 19-33.

Yang, M., Badger, R., \& Yu, Z. (2006). A comparative study of peer and teacher feedback in a Chinese EFL

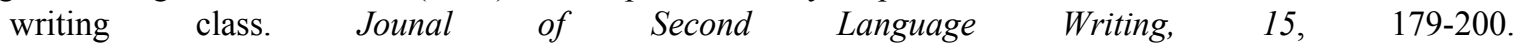
http://dx.doi.org/10.1016/j.jslw.2006.09.004

Yanyan, Z. (2010). Investigating the role of metacognitive knowledge in English writing. HKBU Papers in Applied Language Studies, 14, 25-46. 
Zhao, H. (2014). Investigating teacher-supported peer assessment for EFL writing. ELT Journal, 68(2), 155-168. http://dx.doi.org/10.1093/elt/cct068

Zhu, W. (2001). Interaction and feedback in mixed peer response groups. Journal of Second Language Writing, 10, 251-276. http://dx.doi.org/10.1016/S1060-3743(01)00043-1

\section{Appendix A}

\section{Interview questions}

1. Is peer feedback utilized in your writing class? If so, how is it implemented?

2. What do you think about the effectiveness of current peer feedback practice in your class?

3. How do you engage in peer feedback practice?

4. Do you have any expectations for changes in peer feedback practice? If any, please clarify. 


\section{Appendix B}

\section{The checklist for jigsaw peer feedback}

Name of the feedback giver:

Name of the feedback receiver:

\begin{tabular}{|c|c|c|c|c|c|c|c|c|c|}
\hline & Checklist Questions & & swe & & & & & & How to improve \\
\hline & & & $S(y$ & ith 1 & atin & & NO & EXAMPLES & \\
\hline & & $\mathrm{A}$ & B & $\mathrm{C}$ & $\mathrm{D}$ & $\mathrm{E}$ & & & \\
\hline & $\begin{array}{l}\text { 1. Does the essay provide all } \\
\text { relevant ideas to the topic } \\
\text { given? }\end{array}$ & & & & & & & & \\
\hline & $\begin{array}{l}\text { 2. Does the introduction } \\
\text { clearly introduce the topic } \\
\text { and scope of the essay? }\end{array}$ & & & & & & & & \\
\hline$\sum_{0=1}^{\infty}$ & $\begin{array}{l}\text { 3. Does each paragraph in } \\
\text { the body contain only one } \\
\text { main idea? }\end{array}$ & & & & & & & & \\
\hline 国 & $\begin{array}{l}\text { 4. Are supporting ideas in } \\
\text { each paragraph } \\
\text { well-developed with strong } \\
\text { arguments, evidence, or } \\
\text { proof to persuade readers? }\end{array}$ & & & & & & & & \\
\hline & $\begin{array}{l}\text { 5. Does the essay have an } \\
\text { effective conclusion which } \\
\text { summarises the ideas } \\
\text { mentioned in the } \\
\text { introduction and/or the } \\
\text { author's further comments or } \\
\text { suggestions for the topic } \\
\text { given? }\end{array}$ & & & & & & & & \\
\hline
\end{tabular}

${ }^{*}$ A: excellent; B: very good; C: good; D: fair; E: poor.

Further comments (if any): 
Name of the feedback giver:

Name of the feedback receiver:

\begin{tabular}{|c|c|c|c|c|c|c|c|c|c|}
\hline & Checklist Questions & An & we & & & & & & How to improve \\
\hline & & YE & $8(\mathrm{r}$ & ith & atin & & $\mathrm{NO}$ & EXAMPLES & \\
\hline & & A & $\bar{B}$ & $\bar{C}$ & $\mathrm{D}$ & $\mathrm{E}$ & & & \\
\hline & $\begin{array}{l}\text { 1. Is the essay clearly } \\
\text { organised in three main parts: } \\
\text { introduction, body, and } \\
\text { conclusion and written in } \\
\text { separate paragraphs? }\end{array}$ & & & & & & & & \\
\hline & $\begin{array}{l}\text { 2. Is the length of each } \\
\text { paragraph appropriate (i.e., } \\
\text { not too short or too long)? }\end{array}$ & & & & & & & & \\
\hline$\underset{3}{3}$ & $\begin{array}{l}\text { 3. Does each paragraph in the } \\
\text { body have a topic sentence? }\end{array}$ & & & & & & & & \\
\hline 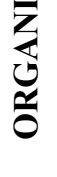 & $\begin{array}{l}\text { 4. Are paragraphs ordered } \\
\text { logically according to an } \\
\text { organizing principle, such as } \\
\text { time, importance, views...? }\end{array}$ & & & & & & & & \\
\hline & $\begin{array}{l}\text { 5. Are appropriate connecting } \\
\text { words such as "and", "but", } \\
\text { "in addition", "furthermore", } \\
\text { however"...smoothly used to } \\
\text { link ideas in the same } \\
\text { paragraph or between/among } \\
\text { paragraphs? }\end{array}$ & & & & & & & & \\
\hline & $\begin{array}{l}\text { 6. Are pronouns "It", "They", } \\
\text { "This", and "These" used to } \\
\text { refer back to a subject? }\end{array}$ & & & & & & & & \\
\hline
\end{tabular}

* A: excellent; B: very good; C: good; D: fair; E: poor

Further comments (if any): 
Name of the feedback giver:

Name of the feedback receiver:

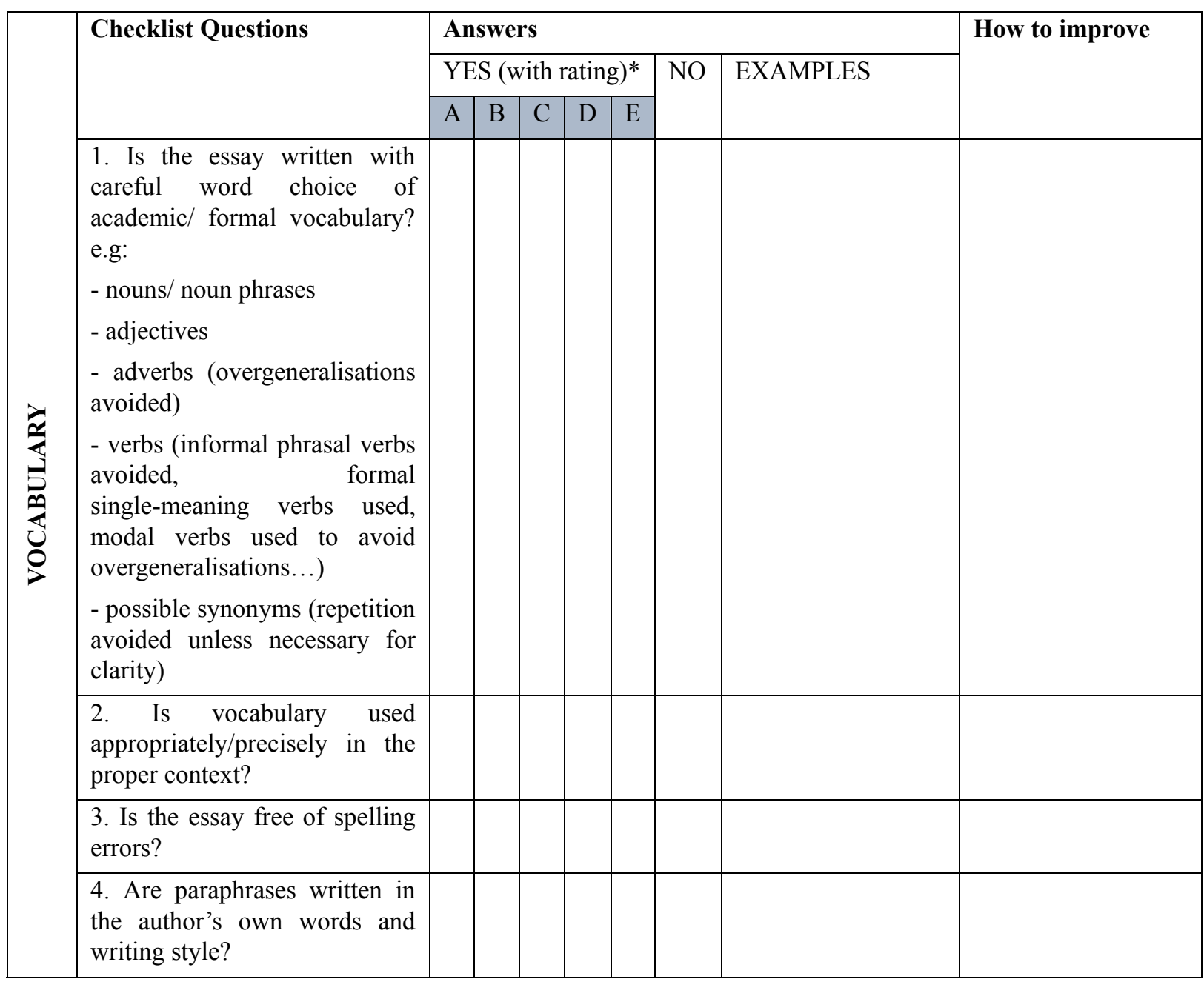

${ }^{*}$ A: excellent; B: very good; C: good; D: fair; E: poor

Further comments (if any): 
Name of the feedback giver:

Name of the feedback receiver:

\begin{tabular}{|c|c|c|c|c|c|c|c|c|c|}
\hline & Checklist Questions & An & swe & & & & & & How to improve \\
\hline & & $\mathrm{YE}$ & $S(\mathrm{r}$ & ith & atin & & $\mathrm{NO}$ & EXAMPLES & \\
\hline & & A & B & $\mathrm{C}$ & $\mathrm{D}$ & $\mathrm{E}$ & & & \\
\hline & $\begin{array}{l}\text { 1. Is the essay written with } \\
\text { correct tenses/voices/forms? }\end{array}$ & & & & & & & & \\
\hline 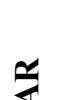 & $\begin{array}{l}\text { 2. Is the essay free of errors } \\
\text { with subject-verb agreement? }\end{array}$ & & & & & & & & \\
\hline$\sum_{j}$ & $\begin{array}{l}\text { 3. Is the essay written with } \\
\text { appropriate punctuation? }\end{array}$ & & & & & & & & \\
\hline 先 & $\begin{array}{l}\text { 4. Is the essay written with a } \\
\text { wide and balanced range of } \\
\text { correct sentence structures } \\
\text { (simple, compound, and/or } \\
\text { complex sentences)? }\end{array}$ & & & & & & & & \\
\hline & $\begin{array}{l}\text { 5. Is the essay written in a } \\
\text { straightforward and concise } \\
\text { style? (no wordiness) }\end{array}$ & & & & & & & & \\
\hline
\end{tabular}

${ }^{*}$ A: excellent; B: very good; C: good; D: fair; E: poor

Further comments (if any):

\section{Copyrights}

Copyright for this article is retained by the author(s), with first publication rights granted to the journal.

This is an open-access article distributed under the terms and conditions of the Creative Commons Attribution license (http://creativecommons.org/licenses/by/3.0/). 